\title{
Niemiecka chadecja wobec Brexitu
}

Referendum w sprawie członkostwa Wielkiej Brytanii w Unii Europejskiej, w którym większość głosujących opowiedziała się za opuszczeniem wspólnoty przez państwo, odbyło się 23 czerwca 2016 r. Komentując jego wyniki kanclerz RFN i jednocześnie przewodnicząca Unii Chrześcijańsko-Demokratycznej Niemiec (CDU) - Angela Merkel podkreślała, że ów dzień ,,jest przełomowy dla Europy. Jest cezurą dla procesu integracji europejskiej. Co konsekwencje tej cezury będą oznaczać w ciągu najbliższych kilku dni, tygodni, miesięcy i lat, będzie w decydującym stopniu zależeć od tego, czy my, pozostałe 27 państw członkowskich Unii Europejskiej, okażemy się chętni i zdolni do tego, by w tej sytuacji nie wyciągać $\mathrm{z}$ referendum szybkich i prostych wniosków, które tylko podzielą Europę, ale czy będziemy gotowi i będziemy mogli analizować i oceniać sytuację ze spokojem i rozwagą oraz na tej podstawie wspólnie podejmować właściwe decyzje" (Pressestatement von Bundeskanzlerin Merkel zum Ausgang..., 2016; EU ist stark genug..., 2016). W podobnym tonie wypowiadał się Alexander Dobrindt. Według byłego sekretarza generalnego Unii Chrześcijańsko-Społecznej oraz przewodniczącego grupy CSU w Bundestagu, Brexit i sposób w jaki zostanie przeprowadzony zdeterminują przyszłe losy Unii Europejskiej i Europy (Alexander Dobrindt (CDU/CSU), 2019, s. 10499 A-B).

Szanując wolę większości Brytyjczyków, Unia Chrześcijańsko-Demokratyczna wyraziła żal z powodu wyniku referendum ${ }^{1}$. Jednocześnie w przyjętej podczas 29 zjazdu CDU uchwale podkreślono, że ów wynik ma swoje źródło w tym, że UE nie reaguje na pojawiające się kryzysy wystarczająco szybko i spójnie. W związku z tym partia postulowała, by lepiej stawiać czoło najważniejszym wyzwaniom. Zobowiązała się także do podjęcia działań, których efektem będzie „silniejsze demonstrowanie przez Europę zdolności do działania oraz do rozwiązywania konkretnych i ważnych problemów" (,, Orientierung in schwierigen Zeiten..., 2016). Przy tym CDU podkreślała, iż „,negocjacje w sprawie Brexitu należy [...] prowadzić mądrze" (Beschluss C 53, C 103..., 2016, s. 29-30). W podobnym tonie wypowiadała się Unia Chrześcijańsko-Społeczna (CSU), która w przyjętej podczas 81 zjazdu uchwale wyraziła przekonanie, że wyjście W. Brytanii z Unii „musi przebiegać w sposób uczciwy i uporządkowany” (Leitantrag „,Linksrutsch verhindern..., 2016, s. 56) ${ }^{2}$. Obie niemieckie partie chadeckie oraz ich

${ }^{1}$ Ubolewanie nad planowanym wystąpieniem Zjednoczonego Królestwa z Unii Europejskiej pojawiało się również w dokumentach CSU oraz we wspólnych dokumentach obu partii (np. ,,Unser Europa macht stark. Für Sicherheit, Frieden und Wohlstand”...., 2019, s. 21). Z kolei Manfred Weber, przewodniczący Europejskiej Partii Ludowej w Parlamencie Europejskim, nazwał Brexit „historycznym błędem” (Wahlen in Großbritannien: Lasst..., 2019).

${ }^{2}$ Stanowisko to zostało powtórzone jeszcze w kilku dokumentach (,,Deutsche Interessen in der Außenpolitik”..., 2016, s. 3; „Der Bayernplan..., 2017, s. 29). 
czołowi przedstawiciele opowiadali się zatem za podpisaniem odpowiedniej umowy wyjściowej między UE a W. Brytanią. Według członka grupy parlamentarnej CDU/ CSU i Komisji do spraw Unii Europejskiej - Detlefa Seifa - opuszczenie organizacji bez sporządzenia odpowiedniego dokumentu, nie tylko nie leżało w interesie obu stron, ale doprowadziłoby do deformacji stosunków i niepewności partnerów, co do podstaw dalszej współpracy (Detlef Seif (CDU/CSU), 2019, s. 10503 D).

Celem artykułu jest zbadanie w jaki sposób Unia Chrześcijańsko-Demokratyczna i Unia Chrześcijańsko-Społeczna odnoszą się do wystąpienia Wielkiej Brytanii z Unii Europejskiej oraz jakie kwestie dotyczące tego procesu najczęściej poruszane są w dokumentach partyjnych i wypowiedziach czołowych przedstawicieli obu niemieckich partii chadeckich. W związku z powyższym, artykuł podzielony został na następujące części: I. Integracja europejska - jej kierunek i wartości w obliczu Brexitu, II. Stosunki handlowe i gospodarcze Unii z W. Brytanią po Brexicie oraz III. Obrona i bezpieczeństwo UE w kontekście Brexitu.

Zakres chronologiczny analizy obejmuje okres od połowy 2016 do początku 2020 roku, czyli od ogłoszenia wyników referendum w sprawie członkostwa W. Brytanii we wspólnocie do momentu, w którym państwo to oficjalnie przestało być jej członkiem. Hipotezą badawczą jest twierdzenie, że zagadnienia poruszane przez CDU oraz CSU w kontekście Brexitu odnoszą się przede wszystkim do podstaw i przyszłego rozwoju Unii Europejskiej oraz formy współpracy Republiki Federalnej Niemiec i Wspólnoty z W. Brytanią.

Podczas pisania artykułu użyta została metoda porównawcza, dzięki której przybliżone i zestawione zostały poglądy obu partii i ich czołowych przedstawicieli dotyczące Brexitu. Wykorzystana została również analiza treści, która umożliwiła zbadanie i zinterpretowanie dokumentów pierwotnych ${ }^{3}$ CDU i CSU oraz stenogramów wystąpień przedstawicieli obu partii przed Bundestagiem.

\section{Integracja europejska - jej kierunek i wartości w obliczu Brexitu}

Zarówno Unia Chrześcijańsko-Demokratyczna Niemiec, jak i Unia Chrześcijańsko-Społeczna łączą integrację europejską z zapewnieniem długotrwałego pokoju, wolności i dobrobytu na kontynencie europejskim (,Freiheit und Sicherheit”..., 2007, s. 97-98; ,, Orientierung in schwierigen Zeiten..., 2016, s. 19; Die Ordnung, 2016, s. 35, 39; „Für ein bürgerliches Europa”, 2017). Zgodnie z programem podstawowym CSU z 2016 r., zjednoczenie Europy jest „,najważniejszą ideą polityczną i największym wkładem w stabilność w XX w." (Die Ordnung, 2016, s. 35, 39). Obie partie przedstawiają Unię Europejską jako zwieńczenie tego procesu, a zatem wyjątkową wspólnotę opartą nie tylko na ww. wartościach, ale również gwarantującą stabilność, demokrację i praworządność oraz broniącą interesów (gospodarczych, społecznych, środowiskowych, zagranicznych i bezpieczeństwa) państw członkowskich (Pressestatement von Bundeskanzlerin Merkel zum Ausgang..., 2016).

${ }^{3}$ Za Z. Blokiem przyjęto, iż do dokumentów pierwotnych zalicza się programy partii, statuty i deklaracje ideowe, uchwały najwyższych organów (również stenogramy z ich obrad, referatów i sprawozdań wygłaszanych przez liderów partyjnych), wywiady z czołowymi działaczami, ich artykuły i inne publikacje oraz relacje z konferencji prasowych (Blok, 1998, s. 44). 
Według A. Merkel, wynik referendum brexitowego ujawnił, ,że ludzie odczuwają zasadnicze wątpliwości co do kierunku, jaki obrał proces integracji europejskiej” (Pressestatement von Bundeskanzlerin Merkel zum Ausgang..., 2016) ${ }^{4}$. W tym kontekście podczas 29 zjazdu partii w grudniu 2016 r., Unia Chrześcijańsko-Demokratyczna krytycznie zauważyła, że „dyskusje dotyczące pogłębienia współpracy przynoszą efekt odwrotny" od zamierzonego, czyli brak akceptacji dla Unii Europejskiej przez obywateli. Przy tym należy zaznaczyć, że partia nie zamierzała rezygnować z pogłębiania integracji europejskiej i podkreślała, że opowiada się za podejmowaniem decyzji w Unii Europejskiej metodą wspólnotową, która ,zapewnia zdolność do działania, legitymację demokratyczną i przejrzystość" (Beschluss C 53, C 103 ..., 2016, s. 30). Przeciwne zdanie w tej kwestii wyrażała CSU, według której referendum brexitowe ujawniło słabości Unii i jej instytucji. Partia podkreślała zatem, że jeśli Europa chce wspólnie kształtować przyszłość i utrzymać swój globalny wpływ, to zamiast „coraz ściślejszego związku” potrzebuje „coraz lepszego związku”.

Zgodnie z CDU, decyzja Brytyjczyków pokazała, że ,projekt europejski jest podatny na zagrożenia i jeszcze długo nie będzie nieodwracalny”. Postulowała, by lepiej stawiać czoło najważniejszym wyzwaniom, tak aby „wartość integracji europejskiej stała się oczywista, zwłaszcza w zakresie praktycznym” (,Orientierung in schwierigen Zeiten..., 2016, s. 19-20). Według Unii Chrześcijańsko-Demokratycznej „bez Unii Europejskiej pojedyncze państwa członkowskie są zbyt słabe, aby być słyszalne na świecie”. Przedstawiła zatem proces integracji jako odpowiedź na globalizację oraz domagała się wyraźnego wskazywania na korzyści, jakie Unia Europejska przynosi wszystkim obywatelom. Przy tym Europa miała stać się silniejsza oraz bliższa obywatelom, ale pozostawiając im "wystarczającą swobodę kształtowania środowiska życia" (Beschluss C 158, 2016, s. 51; Beschluss C 53, C 103, 2016, s. 30). W podobnym tonie wypowiadała się chadecja bawarska podkreślając, że ,jedność w różnorodności jest siłą [...] i kreatywnym napędem Europy” (Die Ordnung, 2016, s. 35, 39; „Für ein bürgerliches Europa”, 2017).

Obie partie zwracały uwagę na fakt, że Europa jest wyjątkową wspólnotą opartą na chrześcijańsko-zachodnich wartościach. Dodawały przy tym, że W. Brytania, która jest jej częścią, nie powinna być z niej wykluczana po Brexicie (,,Unser Europa macht stark..., 2019, s. 21). W związku z powyższym A. Dobrindt sugerował, aby w przyszłości nie wiązać owej wspólnoty wartości z organizacją, ale postrzegać ją ,jako wspólny obszar kulturowy, który chce się dalej rozwijać" (Alexander Dobrindt (CDU/ CSU), 2019, s. 10497 D-10498 B) $)^{6}$. Już podczas listopadowego zjazdu partii w 2016 r., CSU pragmatycznie podkreślała, że dalsze utrzymywanie bliskiej więzi z W. Brytanią,

${ }^{4}$ Przewodnicząca CDU podkreśliła przy tym, iż obawy te występują również wśród obywateli innych państw członkowskich. W podobnym tonie wypowiadał się były poseł PE i były przewodniczący frakcji CDU/CSU w Bundestagu - Friedrich Merz, dodając, iż przez to, że państwa członkowskie nie dzielą już przekonań na temat przyszłości Europy, Unia Europejska coraz bardziej traci spójność (Friedrich Merz, 2018, s. 88).

${ }^{5}$ Podkreślono zatem, że Unia Europejska musi nadać sobie priorytety, jakich oczekują od niej ludzie i gospodarka (Antrag-Nr. J 11, 2016, s. 444-445, 447).

${ }^{6}$ Według polityka „mamy wszelkie powody do dumy z tej Europy. Rozwinęliśmy kontynent wojen w kontynent pokoju i wolności, oparty na wspólnych wartościach chrześcijańsko-zachodnich" (Alexander Dobrindt (CDU/CSU), 2019, s. 10497 D-10498 B). 
w tym współpraca w kwestiach dotyczących bezpieczeństwa oraz afirmowanie podzielanych wartości: wolności, sprawiedliwości, demokracji i gospodarki wolnorynkowej, leży w interesie Niemiec (Antrag-Nr. J 9, 2016, s. 442). Jednocześnie partia dodawała, że „,bez względu na to, jak bardzo sympatyzujemy z Wielką Brytanią, będziemy bronić jedności 27 pozostałych państw członkowskich, aby zabezpieczyć osiągnięcia naszej Europy” (Leitantrag „,Unser Europa ..., 2019, s. 18). W podobnym tonie wypowiadał się Friedrich Merz, który przywołał w tym kontekście szczególną rolę Republiki Federalnej Niemiec. Według byłego posła PE i byłego przewodniczącego grupy CDU/CSU w Bundestagu, Niemcy znajdują się w „geostrategicznym centrum Europy. Jesteśmy zdecydowanie najbardziej zaludnionym krajem w Europie. Zatem [...] czy nam się to podoba, czy nie, ponosimy odpowiedzialność za przyszłość Unii Europejskiej, za to, czy Europa pozostanie razem i czy będziemy rozwijać wspólną przyszłość Europy. W tym celu Niemcy - chcę to wyraźnie powiedzieć [...] - muszą wnieść duży wkład" (Friedrich Merz, 2018, s. 88).

Należy podkreślić, że chadecy niemieccy są głęboko zaangażowani w proces integracji europejskiej od zakończenia II wojny światowej. Do grona „ojców zjednoczonej Europy" zaliczany jest kanclerz RFN Konrad Adenauer, który postulował budowę Europy demokratycznej, żyjącej w pokoju, wolnej od nacjonalizmów i ksenofobii, w której narody połączyłyby się na gruncie wywodzącej się z chrześcijaństwa kultury europejskiej. Co więcej, chadecy, w tym Adenauer, jego następca Ludwig Erhard, ale również przewodniczący Komisji Europejskiej Walter Hallstein oraz minister finansów i przewodniczący CSU Franz Josef Strauß opowiadali się za szerszą współpracą z Zachodem, która obejmowałaby coraz więcej państw, w tym Wielką Brytanię (Bojkało, 1995, s. 73; Miecznikowska, 2007, s. 90; Żurek, 2012, s. 193-194; Bielawska, 2019, s. 55-59). Po akcesji tego państwa do Wspólnot Europejskich, Brytyjczycy stali się ważnym sojusznikiem Niemiec Zachodnich, a później zjednoczonych Niemiec, pomimo, że przejawiali odmienne podejście do pogłębiania integracji europejskiej - byli przeciwni federalizacji Unii Europejskiej i pogłębiania integracji w płaszczyźnie politycznej i gospodarczej, za którymi opowiadała się nie tylko niemiecka chadecja, ale np. również współrządząca z CDU/CSU w latach 1966-1969, 2005-2009 i od 2013 r. najstarsza z działających w Niemczech partia - $\mathrm{SPD}^{7}$. W dużej mierze, to właśnie eurosceptyzm polityków i społeczeństwa brytyjskiego, w tym brak identyfikacji z Unią Europejską oraz krytyka kierunku rozwoju UGiW i uprawnień unijnych instytucji, stały się przyczyną wyjścia Zjednoczonego Królestwa z Unii Europejskiej.

7 Przykładowo, podczas obrad konferencji międzyrządowej poświęconej unii politycznej (1990/1991 r.), przedstawiciele W. Brytanii sceptycznie odnosili się do utworzenia ww. unii i nie zgadzali się na przyznanie PE prawa do współdecydowania w innych sprawach niż te dotyczące rynku wewnętrznego. Ponadto Brytyjczycy sprzeciwiali się powołaniu do życia UGiW i wprowadzeniu wspólnej waluty (konferencja międzyrządowa 1990/91). Podczas prezydencji irlandzkiej (lipiecgrudzień 1996 r.) sprzeciwiali się rozszerzeniu zakresu stosowania procedury podejmowania decyzji większością kwalifikowaną w RUE na nowe polityki, rozszerzeniu kompetencji Parlamentu Europejskiego oraz inkorporacji UZE do UE. Podczas spotkania RE w Amsterdamie (czerwiec 1997 r.) strona brytyjska nie wyrażała zgody na wprowadzenie wzmocnionej współpracy do WPZiB (Węc, 2017, s. 17-21, 24-25, 28). 


\section{Stosunki handlowe i gospodarcze Unii z W. Brytanią po Brexicie}

Obok zagadnień związanych z kierunkiem i podstawami integracji europejskiej, chadecja niemiecka często poruszała kwestię przyszłych stosunków handlowych i gospodarczych Unii Europejskiej ze Zjednoczonym Królestwem oraz negatywnych konsekwencji, jakie poniesie unijny rynek wewnętrzny ze względu na Brexit. Uważając, że wyjście Wielkiej Brytanii z organizacji osłabi ww. rynek, obie partie wiązały negocjacje z koniecznością jego wzmocnienia, w tym z zachowaniem swobody przepływu osób, towarów, usług i kapitału w państwach członkowskich Unii oraz podjęciem nowych działań na jego rzecz, co miało w konsekwencji doprowadzić do zwiększenia konkurencyjności UE na świecie. Kanclerz A. Merkel i jednocześnie przewodnicząca CDU przekonywała, że działanie takie leży zarówno w interesie niemieckim, jak i europejskim (Bericht der Vorsitzenden der CDU Deutschlands, 2016, s. 29; Beschluss C 53, C 103, 2016, s. 29-30; Antrag-Nr. J 9, 2016, s. 442). W podobnym tonie wypowiadał się zarząd CSU w uchwale przyjętej w 2017 r. (,,Für ein bürgerliches Europa”, 2017, s. 3). Ponadto w kontekście niwelowania negatywnego wpływu Brexitu na jednolity rynek, Unia Chrześcijańsko-Demokratyczna nawoływała do zachowania multilateralizmu (Beschluss Nr. C 34, 2019, s. 8).

Brexit powiązany został przez niemieckich chadeków również z obowiązkiem respektowania czterech swobód przez państwa, które chcą mieć dostęp do rynku wewnętrznego, w tym przez W. Brytanię po wyjściu z organizacji. Chadecja wielokrotnie podkreślała, że jest to warunek, który Brytyjczycy muszą bezwzględnie spełnić. Przy tym CDU i CSU sprzeciwiały się tzw. „wybieraniu rodzynków” (niem. Rosinenpickerei), czyli w tym kontekście, czerpaniu wszelkich korzyści ze wspólnego rynku, bez respektowania wszystkich uregulowań prawnych jego dotyczących (Beschluss C 53, C 103, 2016, s. 29-30; Antrag-Nr. J 9, 2016, s. 442; Bericht der Vorsitzenden der CDU Deutschlands, 2016, s. 29). Podkreślając, że zachowanie przez Brytyjczyków dostępu do jednolitego rynku europejskiego, będzie korzystne zarówno dla Niemiec ${ }^{8}$, Unii Europejskiej, jak i W. Brytanii, chadecja zwracała uwagę na fakt, że państwo opuszczające UE, nie może mieć dostępu do wszystkich profitów wynikających z przynależności do Wspólnoty (Antrag-Nr. J 9, 2016, s. 442; „,Für ein Deutschland..., 2017, s. 58; Wahlen in Großbritannien: Lasst..., 2019). Zaznaczała również, że połączenie rynku unijnego i brytyjskiego nie może ujemnie wpłynąć na funkcjonowanie tego pierwszego (,, Unser Europa macht stark..., 2019, s. 21)9.

Kontynuowanie intensywnych więzi gospodarczych z W. Brytanią, po wyjściu tego państwa z Unii, miało zostać osiągnięte poprzez zawarcie umowy handlowej, przy czym bawarska chadecja postulowała, by była ona możliwie jak najbliższa istnie-

${ }^{8}$ Szczególnie często nawiązywała do tego CSU, podkreślając np., że Wielka Brytania jest bardzo ważnym krajem eksportowym dla Bawarii (,Deutsche Interessen in der Außenpolitik”, 2016, s. 3; „Der Bayernplan..., 2017, s. 29).

${ }^{9} \mathrm{~W}$ programie rządowym CDU/CSU na lata 2017-2021 rozwijanie silnych więzi gospodarczych i politycznych ze Zjednoczonym Królestwem powiązano, m.in. z ograniczeniem negatywnego wpływu Brexitu na unijną gospodarkę (,,Für ein Deutschland, 2017, s. 58). Identyczne zapisy znalazły się w uchwale przyjętej przez zarząd CSU we wrześniu 2016 r. (,Deutsche Interessen in der Außenpolitik", 2016, s. 3). 
jącemu status quo, a jednocześnie nie zawierała nieuprawnionych „przepisów specjalnych” (,,Deutsche Interessen in der Außenpolitik”, 2016, s. 3; Leitantrag „Linksrutsch verhindern..., 2016, s. 56; „Der Bayernplan..., 2017, s. 29; Merkel chce umowy..., 2019; Brexitu w obszarze obronności..., 2020). CSU podkreślała, że odrzuca „zarówno uprzywilejowanie, jak i karanie Wielkiej Brytanii. Ani nie powinno być raju podatkowego na progu UE, ani nie chcemy zerwać naszych bliskich więzi gospodarczych, kulturalnych i politycznych z Wielką Brytanią” (,Für ein bürgerliches Europa”, 2017, s. 3). W tym kontekście Manfred Weber podnosił, że umowa handlowa Unii z W. Brytanią będzie kształtować unijne stosunki z innymi krajami trzecimi. W związku z tym przynależący do CSU przewodniczący grupy poselskiej Europejskiej Partii Ludowej w Parlamencie Europejskim uznał, że organizacja powinna wyraźnie bronić swoich interesów podczas pertraktacji. Słusznie prognozował, że negocjacje nad umową handlową będą znacznie bardziej skomplikowane niż nad umową brexitową (Wahlen in Großbritannien: Lasst..., 2019).

Chadecja zwracała także uwagę na konsekwencje wyjścia Zjednoczonego Królestwa z unii celnej, które wiązałyby się m.in. z wprowadzeniem kontroli celnych na zewnętrznych granicach UE, a zatem między Republiką Irlandii i Irlandią Północną. W związku ze złożoną historią łączącą Irlandię z W. Brytanią oraz faktem, że Irlandia Północna podczas referendum opowiedziała się za pozostaniem w UE, Angela Merkel nawoływała m.in. do respektowania zapisów tzw. porozumienia wielkopiątkowego (ang. Good Friday Agreement) ${ }^{10}$. Uznała przy tym, że ,dzięki dokumentom dotyczącym wystąpienia [z UE - przyp. A.B.], [...] poczynione zostały ważne i moim zdaniem wystarczające kroki" (Dr. Angela Merkel, Bundeskanzlerin, 2019, s. 10479 D) ${ }^{11}$.

CDU oraz CSU zwracały również uwagę na negatywne dla obywateli państw członkowskich i Zjednoczonego Królestwa aspekty opuszczenia organizacji. Postulowali zatem, aby każda ze stron uczyniła wszystko, co możliwe, by skutki były jak najmniej odczuwalne. W tym kontekście bawarska chadecja wspominała o zagwarantowaniu praw „obywatelom UE mieszkającym w W. Brytanii i Brytyjczyków, którzy znaleźli u nas drugi dom, i znajdą go również w przyszłości” (, Für ein Deutschland..., 2017, s. 58; Leitantrag „Unser Europa ..., 2019, s. 18). Przy tym należy podkreślić, że w Zjednoczonym Królestwie mieszka i pracuje trzykrotnie więcej osób pochodzenia niemieckiego (głównie naukowcy, studenci i wykwalifikowana siła robocza), niż w Niemczech osób pochodzenia brytyjskiego ${ }^{12}$.

Warto nadmienić, że choć początkowo chadecy niemieccy byli sceptyczni wobec integracji Europy Zachodniej typu gospodarczego, gdyż uważano ją za element prowadzący do integracji politycznej (Wiaderny-Bidzińska, 2000, s. 50), CDU poparła ideę powstania Europejskiej Wspólnoty Gospodarczej, uznała bowiem, że wprowadzenie jednolitego rynku europejskiego na miejsce „narodowych gospodarek, z ich tenden-

${ }^{10}$ Porozumienie m.in. zniosło kontrole graniczne między Irlandią i Irlandią Północną.

${ }^{11}$ Zob. także: Umowa o wystapieniu Zjednoczonego Królestwa..., 2019; Deklaracja polityczna..., 2019; Instrument dotyczacy Umowy..., 2019; Wspólne oświadczenie uzupetniające deklarację polityczna..., 2019.

${ }^{12}$ W 2013 r. w W. Brytanii mieszkało 311,3 tys. osób urodzonych w Niemczech, natomiast w Republice Federalnej Niemiec 96,9 tys. osób pochodzenia brytyjskiego (Borońska-Hryniewiecka, Kaca, Płóciennik, Toporowski, 2016, s. 27). 
cją do zamknięcia i utrudniania wymiany towarów, [...] umożliwi swobodny rozwój sił wytwórczych i zapewni dobrobyt narodom”. Przyjmując z zadowoleniem początki współpracy gospodarczej w Europie Zachodniej, partia obiecywała, że będzie „wspierać wszelkie dalsze kroki w tym kierunku w celu urzeczywistnienia wolnej konkurencji i wymiany usług między narodami Europy" (Das Hamburger Programm ..., 1953, s. 258). Ówczesny minister gospodarki Ludwig Erhard przekonywał, że kooperacja z państwami zachodnimi jest koniecznością, gdyż „,...] gospodarka Republiki Federalnej nie będzie mogła funkcjonować, nie wspominając o jej rozwijaniu. Możemy istnieć tylko w bezpośrednim związku z resztą świata" (Bundeswirtschaftsminister Prof. Dr. Erhard, 1953, s. 144). W tym kontekście W. Brytania była i w zasadzie, jako ważny rynek eksportowy dla Niemiec, wciąż jest traktowana priorytetowo. Według danych Federalnego Urzędu Statystycznego z 2020 r. państwo to jest dla Niemiec piątym - po USA, Francji, Chinach i Holandii - rynkiem eksportowym (jego wartość wyniosła w 2019 r. niemal 80 mld euro, dla porównania przed referendum brexitowym w $2015 \mathrm{r}$. było to niemal 90 mld euro) (Rangfolge der Handelspartner..., 2020; Rangfolge der Handelspartner..., 2016).

Do W. Brytanii trafiają zaawansowane dobra wysokiej jakości (np. pojazdy, maszyny, urządzania do przetwarzania danych, urządzenia elektryczne oraz optyczne), ale także, choć w mniejszym stopniu, usługi (Borońska-Hryniewiecka, Kaca, Płóciennik, Toporowski, 2016, s. 24). Uwzględniwszy powyższe, chadecja stoi na stanowisku, że członkostwo tego państwa w rynku wewnętrznym i unii celnej byłoby najlepszym rozwiązaniem dla Niemiec, ale także Unii Europejskiej i Zjednoczonego Królestwa.

\section{Obrona i bezpieczeństwo UE w kontekście Brexitu}

Odnosząc się do negocjacji w sprawie Brexitu, CDU i CSU często podnosiły także kwestię współpracy Unii Europejskiej ze Zjednoczonym Królestwem w obszarze obrony i bezpieczeństwa po opuszczeniu przez to państwo organizacji. Kanclerz Angela Merkel zapewniała, że Niemcy i Unia Europejska życzą sobie dobrych i bliskich relacji z W. Brytanią. Mając na względzie poprawę europejskich zdolności do działania i zapewnienia bezpieczeństwa na kontynencie, polityk podkreślała, że państwo to musi być zawsze brane pod uwagę przy tworzeniu planów dotyczących Europy (Dr. Angela Merkel, Bundeskanzlerin, 2019, s. 10479 D-10480 A). CDU dodawała, że celem jest wspólne wypracowanie koncepcji, np. antyterrorystycznych, które sprawią, że Europa będzie „silna i zjednoczona” (Beschluss C 53, C 103, 2016, s. 29-30) ${ }^{13}$. W związku z powyższym, według niemieckiej minister obrony Annegret Kramp-Karrenbauer, Unia Europejska powinna zaoferować W. Brytanii, po wyjściu tego państwa z organizacji ,uprzywilejowany status strony trzeciej” w ramach współpracy w dziedzinie obrony. Przewodnicząca CDU łączyła go również z dostępem Brytyjczyków do projektów, które realizowane są przez poszczególne państwa członkowskie, jak francusko-niemiecko-hiszpański Future Combat Air System (FCAS) (Wintour, 2020).

${ }^{13} \mathrm{~W}$ podobnym tonie wypowiadał się przewodniczący frakcji CDU/CSU w Parlamencie Europejskim. Według Daniela Caspary’ego „partnerstwo w zakresie polityki bezpieczeństwa z Wielką Brytanią musi być przestrzegane także po Brexicie” (Daniel Caspary MdEP, 2019, s. 10). 
Wątpliwym jest jednak dołączenie W. Brytanii do programu, gdyż państwo to już raz wycofało się z budowy wspólnej platformy bojowej o tej samej nazwie.

Należy przy tym podkreślić, że chadecja zdawała sobie sprawę z potencjalnych trudności we współpracy, które mogą pojawić się ze względu na dotychczasową ambiwalencję W. Brytanii odnośnie rozszerzenia kompetencji UE w obszarze Wspólnej (wcześniej Europejskiej) Polityki Bezpieczeństwa i Obrony, która powiązana jest m.in. ze ścisłym sojuszem tego państwa ze Stanami Zjednoczonymi oraz sprzeciwem wobec tworzenia europejskich struktur, które duplikowałyby natowskie ${ }^{14}$. Chadeccy politycy, w przeciwieństwie do brytyjskich, nie widzieli sprzeczności w pogłębianiu współpracy państw członkowskich UE w tym zakresie przy jednoczesnym zachowaniu roli i znaczenia Paktu Północnoatlantyckiego. Zgodnie z tradycyjną linią chadeckiej polityki europejskiej, A. Kramp-Karrenbauer zwracała uwagę, że europejski filar obrony jest niezmiennie powiązany ze strukturami NATO (Wintour, 2020).

Według A. Merkel, odnosząca się do bezpieczeństwa kontynentu europejskiego współpraca z Wielką Brytanią powinna być również bardzo intensywnie kontynuowana w ramach ONZ (Dr. Angela Merkel, Bundeskanzlerin, 2019, s. 10479 D-10480 A $)^{15}$. Z poglądem tym zgodził się Ralph Brinkhaus. Ponadto przewodniczący frakcji parlamentarnej CDU/CSU w Bundestagu przekonywał, że UE powinna mieć swojego przedstawiciela w Radzie Bezpieczeństwa Organizacji Narodów Zjednoczonych ${ }^{16} \mathrm{i}$,pprzemawiać jednym mocnym głosem" do swych obywateli. Stanowisko to powiązane jest z faktem, że wyjście W. Brytanii z Unii oznacza, że organizacja straci jedno z dwóch (obok Francji) swoich państw członkowskich mających stałe miejsce we wspomnianej Radzie. Uwzględniwszy negatywne konsekwencje dla bezpieczeństwa UE związane ze zmniejszeniem możliwości wpływu na podejmowane w Radzie Bezpieczeństwa ONZ decyzje, Brinkhaus opowiadał się również za stworzeniem Europejskiej Rady Bezpieczeństwa, w której pracach, obok przedstawicieli państw członkowskich UE, uczestniczyć będą Brytyjczycy. Przewidywał, że byłaby to „dobra okazja do dalszego zacieśnienia więzi z Wielką Brytanią”. W tym kontekście postulował „europeizację armii oraz tworzenie wspólnych projektów zbrojeniowych” (Ralph Brinkhaus (CDU/CSU), 2019, s. $10491 \mathrm{~B}-10491 \mathrm{C})^{17}$.

Będąc świadoma, że wyjście W. Brytanii, czyli państwa o znacznym potencjale militarnym i nuklearnym, z Unii Europejskiej negatywnie wpłynie na bezpieczeństwo i możliwości obronne organizacji, chadecja opowiadała się za zacieśnieniem współpracy państw członkowskich $\mathrm{w}$ ramach $\mathrm{WPBiO}$. $\mathrm{Z}$ zadowoleniem przyjęła zainicjowanie w grudniu 2017 r. stałej współpracy strukturalnej (PESCO) w celu wzmocnienia

${ }^{14}$ Alexander Dobrindt podkreślał znaczenie faktu, że rozwój europejskiej polityki bezpieczeństwa jest silnie uzależniony od wsparcia Brytyjczyków (Dobrindt: „, Offene Grenzen ..., 2018).

${ }^{15}$ Kanclerz podkreślała, że współpraca powinna być również kontynuowana w ramach niemiecko-brytyjskich stosunków bilateralnych (Dr. Angela Merkel, Bundeskanzlerin, 2019, s. 10479 D-10480 A). Z poglądem tym zgadzała się CSU, według której dalsze utrzymywanie ściślejszej więzi z Wielką Brytanią w kwestiach dotyczących bezpieczeństwa leży w niemieckim interesie (Antrag-Nr. J9, 2016, s. 442).

${ }_{16}$ Propozycja ta wyszła od Olafa Scholza, wicekanclerza i ministra finansów Niemiec (Słojewska, 2018).

${ }^{17}$ Chęć powiązania W. Brytanii z Europejską Radą Bezpieczeństwa potwierdził minister spraw zagranicznych Heiko Maas (Mark, 2019). 
bezpieczeństwa i obronności Europy. Jak podkreślał rzecznik ds. polityki zagranicznej grupy parlamentarnej CDU/CSU w Bundestagu - Jürgen Hardt ,jest to centralny element pogłębiający Wspólną Politykę Bezpieczeństwa i Obrony Unii Europejskiej. W interesie Niemiec leży rozwój Europy w dziedzinie polityki zagranicznej i obrony. Oznacza on zdecydowanie większe bezpieczeństwo dla wszystkich obywateli”. Dodawał przy tym, że PESCO stanowi kamień milowy w dalszym rozwoju Unii Europejskiej, ponieważ jest powiązana $\mathrm{z}$ dziedziną polityki, która do tej pory podlegała państwom narodowym. Zasugerował również, że RFN powinna odgrywać ważną rolę w ramach owej współpracy (Ständige Strukturierte Zusammenarbeit..., 2017). Zgodnie ze wspomnianą powyżej ambiwalentną polityką W. Brytanii wobec pogłębiania współpracy w dziedzinie bezpieczeństwa i obronności oraz planowanym wyjściem z UE, państwo to zrezygnowało z uczestniczenia w PESCO.

\section{Zakończenie}

W analizowanym okresie, niemieccy chadecy kładli nacisk na fakt, że po opuszczeniu Unii, Wielka Brytania pozostanie ważnym partnerem RFN i UE. W związku z powyższym, byli żywo zainteresowani tym, aby relacje z W. Brytanią pozostały przyjazne, bliskie i konstruktywne (Detlef Seif (CDU/CSU), 2019, s. 10503 D). Przy tym nie zgadzali się zarówno na karanie tego państwa za podjętą decyzję, jak i przyznanie mu uprzywilejowanej pozycji jako byłego członka UE. Ponieważ według chadeków, żaden kraj nie może korzystać z przywilejów związanych z członkostwem w Unii Europejskiej bez wypełniania swoich zobowiązań, odrzucali tzw. „wybieranie rodzynków” (,,Für ein bürgerliches Europa”, 2017, s. 3; ,Unser Europa macht stark..., 2019, s. 21) ${ }^{18}$. Z drugiej strony, chcąc podkreślić znaczenie relacji brytyjsko-unijnych, postulowali przyjęcie modelu bardzo ścisłej współpracy gospodarczej, ale także politycznej w kwestiach związanych z obroną i bezpieczeństwem Europy oraz UE. Według członków CSU miał to być model tzw. „partnerstwa z podwójnym plusem” (niem. „Partnerschaft Doppelplus”)

Warto przy tym nadmienić, że obie partie wielokrotnie podkreślały, że Unia Europejska nie zamyka drzwi przed W. Brytanią, zarówno w kontekście wspomnianej przyjacielskiej współpracy, która, choć nie będzie tak bliska jak przed wystąpieniem tego państwa ze Wspólnoty, przyniesie wzajemne korzyści, ale również ewentualnego powrotu Zjednoczonego Królestwa do Unii (, Unser Europa macht stark..., 2019, s. 21; Antrag-Nr. J 9, 2016, s. 442; Dr. Angela Merkel, Bundeskanzlerin, 2019, s. 10479 D-10480 A; Ralph Brinkhaus (CDU/CSU), 2019, s. 10489 D; Manfred Weber, 2020).

${ }^{18}$ M. Weber podkreślał, że opuszczenie organizacji „oznacza utratę korzyści wynikających z członkostwa w UE" (Wahlen in Großbritannien: Lasst..., 2019).

${ }_{19} \mathrm{~W}$ ramach owego partnerstwa bawarscy chadecy chcieli zagwarantować prawa obywatelom UE mieszkającym w Zjednoczonym Królestwie i odwrotnie, Brytyjczykom mieszkającym w UE oraz ściśle współpracować z W. Brytanią w kwestiach dotyczących bezpieczeństwa i obrony obu podmiotów. CSU łączyła również bliskie partnerstwo z nadzieją na jednoczesny „ponowny proces zbliżenia z UE" (Alexander Dobrindt (CDU/CSU), 2019, s. 10499 A-B; Brexit: CSU will London..., 2018; Alexander Dobrindt (CSU) wegen ..., 2019; ,,Konstruktive”, aber..., 2019). 
Niektórzy przedstawiciele chadecji - np. Annegret Kramp-Karrenbauer - wyrażali nadzieję na powtórne przeprowadzenie referendum, którego konsekwencją mogłoby być powstrzymanie Brexitu (Adler, 2019; Times Letters..., 2019; List znanych Niemców..., 2019). Okazała się ona być płonna. Wejście w życie umowy o wystąpieniu W. Brytanii z Unii Europejskiej Angela Merkel określiła jako głęboką cezurę dla wszystkich. Jednocześnie kanclerz zdawała sobie sprawę, że w trwającej do końca 2020 r. fazie przejściowej, konieczne są intensywne negocjacje, które powinny zakończyć się podpisaniem umowy dotyczącej przyszłych unijno-brytyjskich stosunków w dziedzinie WPBiO (i szerzej WPZiB), ale również odnoszące się do handlu.

CDU i CSU zwracały również uwagę na fakt, że po wyjściu Wielkiej Brytanii z Unii Europejskiej, Republika Federalna Niemiec będzie musiała wziąc na siebie większą odpowiedzialność polityczną, ponieważ utraci ważnego sojusznika, który wspierał wolność, sprawiedliwość, demokrację, pomocniczość oraz gospodarkę wolnorynkową. Obie partie prognozowały, że Niemcy będą musiały zastanowić się nad głębią integracji europejskiej (Antrag-Nr. J 9, 2016, s. 442; Beschluss C 53, C 103, 2016, s. 29-30). Zgadzając się, że Unia Europejska jest gwarantem długotrwałego pokoju, wolności i dobrobytu, partie nie były jednomyślne w kwestii, jak dalece powinna zostać zacieśniona współpraca w obszarze polityki i gospodarki. Tradycyjnie, silniej za głębszą integracją opowiadała się Unia Chrześcijańsko-Demokratyczna. Przy tym należy podkreślić, że wątpliwości wyrażane przez CSU i jej czołowych przedstawicieli, np. byłego przewodniczącego partii Horsta Seehofera, nie stały się przyczyną rozłamu siostrzanych partii, ani ostrej zmiany polityki europejskiej niemieckiej chadecji. Przez wiele lat chadekom udawało się pogłębiać współpracę w gronie zainteresowanych państw członkowskich Wspólnot i Unii Europejskiej, która nie wykluczała rozszerzania organizacji. Paradoksalnie, wyjście z Unii państwa, które kontestowało zacieśnianie współpracy i przyznawanie unijnym instytucjom większych kompetencji, prawdopodobnie nie zatrzyma tego procesu, a raczej stanie się przyczyną usztywnienia Europy „dwóch prędkości”. Jeśli W. Brytania zdecyduje się na ponowne wstąpienie do organizacji, będzie miała nie lada dystans do pokonania, chcąc zbliżyć się do państw rdzenia.

\section{Bibliografia}

\section{I. Źródla:}

\section{Dokumenty unijne}

Deklaracja polityczna określająca ramy przyszłych stosunków między Unią Europejska a Zjednoczonym Królestwem, „Dziennik Urzędowy Unii Europejskiej”, C 066I, rocznik 62, 19.02.2019, https:/eur-lex.europa.eu/legal-content/PL/TXT/?uri=OJ:C:2019:066I:TOC, 21.01.2020.

Deklaracja polityczna określająca ramy przyszłych stosunków między Unią Europejską a Zjednoczonym Królestwem, „Dziennik Urzędowy Unii Europejskiej”, C 34, rocznik 63, 31.01.2020, https://eur-lex.europa.eu/legal-content/PL/TXT/?uri=OJ:C:2020:034:TOC, 2.04.2020.

Instrument dotyczacy Umowy o wystapieniu Zjednoczonego Królestwa Wielkiej Brytanii i Irlandii Pólnocnej z Unii Europejskiej i Europejskiej Wspólnoty Energii Atomowej, Bruksela, 20 marca 2019 r. (OR. en), XT 21014/19, BXT 15, CO EUR-PREP 10, https://data.consilium.europa.eu/doc/document/XT-21014-2019-INIT/pl/pdf, 20.01.2020. 
Umowa o wystapieniu Zjednoczonego Królestwa Wielkiej Brytanii i Irlandii Pólnocnej z Unii Europejskiej i Europejskiej Wspólnoty Energii Atomowej, „Dziennik Urzędowy Unii Europejskiej”, C 066I, rocznik 62, 19.02.2019, https://eur-lex.europa.eu/legal-content/PL/TXT/?uri$=$ OJ:C:2019:066I:TOC, 21.01.2020.

Umowa o wystapieniu Zjednoczonego Królestwa Wielkiej Brytanii i Irlandii Pótnocnej z Unii Europejskiej i Europejskiej Wspólnoty Energii Atomowej, „Dziennik Urzędowy Unii Europejskiej”, L 29/7, rocznik 63, 31.01.2020, https://eur-lex.europa.eu/legal-content/PL/TXT/?uri$=\mathrm{OJ}: \mathrm{L}: 2020: 029:$ TOC, 2.04.2020.

Wspólne oświadczenie uzupetniające deklarację polityczna określająca ramy przyszłych stosunków między Unią Europejska a Zjednoczonym Królestwem Wielkiej Brytanii i Irlandii Pótnocnej, Bruksela, 20 marca 2019 r., (OR. en), XT 21018/19, BXT 24, CO EUR-PREP 11, https:// data.consilium.europa.eu/doc/document/XT-21018-2019-INIT/pl/pdf, 20.01.2020.

\section{Wystąpienia polityków chadeckich}

Alexander Dobrindt (CDU/CSU) (2019), w: Plenarprotokoll 19/89, Deutscher Bundestag, Stenografischer Bericht 89. Sitzung, Berlin, Donnerstag, den 21. März 2019, http://dipbt.bundestag. de/dip21/btp/19/19089.pdf\#P.10479, 10.01.2020.

Bericht der Vorsitzenden der CDU Deutschlands, Bundeskanzlerin Dr. Angela Merkel MdB (2016), w: Protokoll, 29. Parteitag der CDU Deutschlands, 6.-7. Dezember 2016, Essen, Berlin, https://www.kas.de/c/document_library/get_file?uuid=366c1c26-a2d0-9a63-fd5ae63f31a6e828\&groupId=252038, 1.10.2017.

Bundeswirtschaftsminister Prof. Dr. Erhard (1953), w: „Deutschland-sozialer Rechtsstaat im geeinten Europa", 4. Bundesparteitag, 18.-22. April 1953, Hamburg.

Daniel Caspary MdEP, Bericht des Vorsitzenden der CDU/CSU-Gruppe im Europäischen Parlament, 32. Parteitag der CDU Deutschlands (2019), https://www.cdu.de/system/tdf/media/ images/leipzig2019/2019-11-23-bericht-caspary.pdf?file=1, 20.01.2020.

Detlef Seif (CDU/CSU) (2019), w: Plenarprotokoll 19/89, Deutscher Bundestag, Stenografischer Bericht 89. Sitzung, Berlin, Donnerstag, den 21. März 2019, http://dipbt.bundestag.de/dip21/ btp/19/19089.pdf\#P.10479, 20.01.2020.

Dr. Angela Merkel, Bundeskanzlerin (2019), w: Plenarprotokoll 19/89, Deutscher Bundestag, Stenografischer Bericht 89. Sitzung, Berlin, Donnerstag, den 21. März 2019, http://dipbt.bundestag.de/dip21/btp/19/19089.pdf\#P.10479, 20.01.2020.

Friedrich Merz (2018), w: Protokoll, 31. Parteitag der CDU Deutschlands, 7.-8. Dezember 2018, Hamburg, https://www.kas.de/documents/291599/291648/31.+Parteitagsprotokoll_2018_ Internet.pdf/62e3c155-8af0-5cb7-8004-900323d2ad32?t=1560859494371, 20.01.2020.

Pressestatement von Bundeskanzlerin Merkel zum Ausgang des Referendums über den Verbleib Großbritanniens in der Europäischen Union am 24. Juni 2016 in Berlin, Mitschrift Pressekonferenz, Freitag, 24. Juni 2016 (2016), https://www.bundesregierung.de/breg-de/ aktuelles/pressestatement-von-bundeskanzlerin-merkel-zum-ausgang-des-referendumsueber-den-verbleib-grossbritanniens-in-der-europaeischen-union-am-24-juni-2016-844796, 20.01.2020.

Ralph Brinkhaus (CDU/CSU) (2019), w: Plenarprotokoll 19/89, Deutscher Bundestag, Stenografischer Bericht 89. Sitzung, Berlin, Donnerstag, den 21. März 2019, http://dipbt.bundestag.de/ dip21/btp/19/19089.pdf\#P.10479, 20.01.2020.

Manfred Weber (2020), w: European Parliament, Verbatim Report of Proceedings, Wednesday, 29 January 2020, Brussels, http://www.europarl.europa.eu/doceo/document/CRE-9-202001-29_EN.pdf, 20.02.2020.

Ständige Strukturierte Zusammenarbeit stärkt die Europäische Union (2017), Pressemitteilung 18.10.2017, https://www.cducsu.de/presse/pressemitteilungen/staendige-strukturierte-zusammenarbeit-staerkt-die-europaeische-union, 15.03.2020. 


\section{Programy partyjne chadecji}

Antrag-Nr. J 11 „EU-Leitbild 2030. Weniger Regulierung-größerer Mehrwert-gestiegene Verantwortung für Deutschland" (2016), w: Beschlussbuch zum Parteitag 2016, 81. Parteitag der Christlich-Sozialen Union, 04./05. November 2016, München, http://www.csu.de/common/ download/Beschlussbuch_2016_final.pdf, 1.10.2017.

Antrag-Nr. J 9 , Brexit-Verhandlungen zum gegenseitigen Vorteil führen-europäischen Binnenmarkt stärken - keine Sozialversicherungsunion” (2016), w: Beschlussbuch zum Parteitag 2016, 81. Parteitag der Christlich-Sozialen Union, 04./05. November 2016, München, http://www. csu.de/common/download/Beschlussbuch_2016_final.pdf, 1.10.2017.

Beschluss C 158 „Europa stärken und bürgernäher machen” (2016), w: Sonstige Beschlüsse, 29. Parteitag der CDU Deutschlands in Essen, https://www.cdu.de/system/tdf/media/dokumente/cdupt16_sonstige_beschluesse.pdf?file $=1,1.10 .2019$.

Beschluss C 53, C 103 „Europa nach dem Brexit - für eine Union der Bürgerinnen und Bürger” (2016), w: Sonstige Beschlüsse, 29. Parteitag der CDU Deutschlands in Essen, https://www. cdu.de/system/tdf/media/dokumente/cdupt16_sonstige_beschluesse.pdf?file=1, 1.10.2019.

Beschluss Nr. C 34 „Europa 2019-2024. Auf Kernthemen konzentrieren-Subsidiarität leben-ordnungspolitischen Kompass einhalten” (2019), w: Sonstige Beschlüsse des 32. Parteitags der CDU Deutschlands, 32. Parteitag der CDU Deutschlands 22. bis 23. November 2019, Leipziger Messe, https://www.cdu.de/system/tdf/media/images/leipzig2019/32._parteitag_2019_ sonstige_beschluesse_2.pdf?file=1, 1.01.2020.

Das Hamburger Programm der Christlich Demokratischen Union Deutschlands für den Zweiten Deutschen Bundestag (1953), w: ,,Deutschland-sozialer Rechtsstaat im geeinten Europa”, 4. Bundesparteitag, 18.-22. April 1953, Hamburg.

„Deutsche Interessen in der Außenpolitik”, Beschluss des CSU-Parteivorstands, 9./10. September 2016, Schwarzenfeld (2016), https://www.csu.de/common/csu/content/csu/hauptnavigation/ politik/beschluesse/Papiere/Deutsche_Interessen_in_der_Aussenpolitik_Beschluss_final. pdf, 20.01.2020.

„Der Bayernplan. Klar für unser Land”, Beschluss des CSU-Parteivorstands am 17. Juli 2017 in München (2017), https://www.csu.de/common/csu/content/csu/hauptnavigation/politik/beschluesse/Beschluss_Bayernplan_BF.pdf, 1.10.2017.

Die Ordnung, Grundsatzprogramm der Christlich-Sozialen Union, Beschluss des CSU-Parteitags am 5.11.2016 in München (2016), https://www.hss.de/fileadmin/user_upload/HSS/Dokumente/ACSP/Grundsatzprogramme/CSU_Grundsatzprogramm_2016.pdf, 1.10.2017.

„Freiheit und Sicherheit”, Grundsätze für Deutschland. Das Grundsatzprogramm. Beschlossen vom 21. Parteitag, Hannover, 3.-4. Dezember 2007 (2007), https://www.cdu.de/system/tdf/media/ dokumente/071203-beschluss-grundsatzprogramm-6-navigierbar_1.pdf?file=1\&type=field collection_item\&id=1918, 1.10.2017.

„Für ein bürgerliches Europa”, Beschluss des CSU-Parteivorstands vom 30. Januar 2017 in München (2017), https://www.csu.de/common/csu/content/csu/hauptnavigation/politik/beschluesse/Papiere/2017-01-30-Europapapier.pdf, 1.10.2017.

„Für ein Deutschland, in dem wir gut und gerne leben”, Regierungsprogramm 2017-2021 (2017), https://www.cdu.de/system/tdf/media/dokumente/170703regierungsprogramm2017. pdf?file $=1,1.10 .2018$.

Leitantrag „Linksrutsch verhindern - Damit Deutschland Deutschland bleibt” (2016), w: Beschlussbuch zum Parteitag 2016, 81. Parteitag der Christlich-Sozialen Union, 04./05. November 2016, München, https://www.csu.de/common/download/Beschlussbuch_2016_final.pdf, 1.10.2017.

Leitantrag ,Unser Europa: Ein Europa der Bürger” (2019), w: Beschlussbuch zum Parteitag 2019, 84. Parteitag der Christlich-Sozialen Union, 19. Januar 2019, München, https://www.csu. 
de/common/csu/content/csu/hauptnavigation/politik/beschluesse/Beschlussbuch_Sonderparteitag_2019_BF.pdf, 20.01.2020.

„Orientierung in schwierigen Zeiten - für ein erfolgreiches Deutschland und Europa”. Beschluss des 29. Parteitags der CDU Deutschlands, Essen, 6-7. Dezember 2016 (2016), https://www. cdu.de/system/tdf/media/dokumente/cdupt16_orientierung_inschwierigenzeitenfuereinerfolgreichesdeutschlandundeuropa_0.pdf?file $=1,1.10 .2017$.

„Unser Europa macht stark. Für Sicherheit, Frieden und Wohlstand”. Gemeinsames Europawahlprogramm von CDU und CSU (2019), https:/www.csu.de/common/csu/content/ csu/hauptnavigation/dialog/infomaterial/2019/CDU_20CSU_Europawahlprogramm_ final_20mit_20deckblatt_BF.pdf, 10.01.2020.

\section{Monografie i prace pod redakcją}

Bielawska A. (2019), Koncepcja unii politycznej niemieckiej chadecji na tle politycznego i gospodarczego rozwoju Unii Europejskiej, Poznań.

Blok Z. (1998), Teoria polityki. Studia, Poznań.

Bojkało W. (1995), Koncepcja Europy Konrada Adenauera i jej realizacja w praktyce politycznej w latach 1945-1954, Wrocław.

Borońska-Hryniewiecka K., Kaca E., Płóciennik S., Toporowski P. (2016), Prawdopodobne stanowisko Niemiec wobec nowego modelu relacji UE-Wielka Brytania po ewentualnym Brexicie, w: Relacje Unia Europejska-Wielka Brytania po ewentualnym brexicie. Stanowiska Niemiec, Francji, Włoch, Hiszpanii i Polski, red. K. Borońska-Hryniewiecka, S. Płóciennik, Warszawa.

Miecznikowska J. (2007), Chadecja niemiecka wobec integracji europejskiej w latach 1949-1998, Warszawa.

Wiaderny-Bidzińska K. (2000), Polityczna integracja Europy Zachodniej, Toruń-Warszawa.

Żurek M. (2012), Unia Europejska w polityce zagranicznej zjednoczonych Niemiec. Determinanty Europapolitik, Szczecin.

\section{Artykuły prasowe}

Adler K. (2019), Brexit: Germany's CDU leader hopes for second referendum, 5.04.2019, https:// www.bbc.com/news/world-europe-47822843, 10.01.2020.

Słojewska A. (2018), Niemcy chca miejsca dla UE w Radzie Bezpieczeństwa ONZ, „Rzeczpospolita” $\mathrm{z}$ dnia 1.12.2018.

von der Mark F. (2019), Szansa na przełom. Niemiecka polityka europejska w roku 2020, 31.12.2019, „DW”, https://www.dw.com/pl/szansa-na-prze\%C5\%82om-niemiecka-polityka-europejskaW-roku-2020/a-51836195, 20.01.2020.

Wintour P. (2020), UK must get post-Brexit “defence privileges”, says German minister, „The Guardian" z dnia 16.01.2020.

Alexander Dobrindt (CSU) wegen des Brexit: ,,Unsere Tür steht immer für Euch offen”, 22.03.2019, „Passauer Neue Presse”, https://www.pnp.de/nachrichten/politik/3266919_Alexander-Dobrindt-CSU-wegen-des-Brexit-Unsere-Tuer-steht-immer-fuer-Euch-offen.html, 10.01.2020.

Angela Merkel: Brexit jest głęboka cezura, 1.02.2020, „DW”, https:/www.dw.com/p1/angela-merkelbrexit-jest-g\%C5\%82\%C4\%99bok\%C4\%85-cezur\%C4\%85/a-52220335, 2.02.2020.

Brexit: CSU will London zum „,Doppel-Plus”-Partner machen, 31.12.2018, „Augsburger Allgemeine Zeitung”, https://www.augsburger-allgemeine.de/politik/Brexit-CSU-will-London-zumDoppel-Plus-Partner-machen-id53047536.html, 1.01.2020.

Brexitu w obszarze obronności nie będzie? „Bezpieczeństwo Europy jest niepodzielne”, 17.01.2020, „Forsal.pl”, https://forsal.pl/swiat/brexit/artykuly/1449084,brexitu-w-obszarze-obronnoscinie-bedzie-bezpieczenstwo-europy-jest-niepodzielne.html, 20.01.2020. 
Dobrindt: „Offene Grenzen am Ärmelkanal und sichere Grenzen am Mittelmeer”, 19.10.2018, https://www.csu-landesgruppe.de/themen/auswaertiges-europa-verteidigung/dobrindt-offene-grenzen-am-aermelkanal-und-sichere-grenzen-am-mittelmeer, 20.01.2020.

EU ist stark genug für die richtigen Antworten, Freitag, 24. Juni 2016, 24.06.2016, https://www.bundesregierung.de/breg-de/aktuelles/eu-ist-stark-genug-fuer-die-richtigen-antworten-250716, 20.01.2020.

„,Konstruktive”, aber erfolglose Gespräche in Brüssel, 20.02.2019, „DW”, https://www.dw.com/ de/konstruktive-aber-erfolglose-gespr\%C3\%A4che-in-br\%C3\%BCssel/a-47606977, 10.01.2020.

List znanych Niemców do Brytyjczyków: Chcemy, żebyście zostali w UE (2019), 18.01.2019, „Gazeta Prawna", https://www.gazetaprawna.pl/artykuly/1393071,brexit-list-niemcow-do-brytyjczykow.html, 20.01.2020.

Merkel chce umowy o wolnym handlu, 18.10.2019, TVN24.pl, https://www.tvn24.pl/wiadomosci-ze-swiata, 2/merkel-ue-i-wielka-brytania-powinny-zawrzec-umowe-o-wolnymhandlu,978436.html, 20.01.2020.

Times Letters: 'German friends' urge Britain to stay in EU (2019), „The Times” z dnia 18.01.2019.

Wahlen in Großbritannien: Lasst uns den Brexit jetzt abschließen, 13.12.2019, https:/www.eppgroup.eu/de/newsroom/nachrichten/lasst-uns-den-brexit-jetzt-abschliessen, 20.01.2020.

\section{Materiały internetowe:}

Rangfolge der Handelspartner im Außenhandel der Bundesrepublik Deutschland (2016), Statistisches Bundesamt, 2016, https://www.destatis.de/DE/ZahlenFakten/GesamtwirtschaftUmwelt/Aussenhandel/Handelspartner/Tabellen/RangfolgeHandelspartner.pdf?_blob=publicationFile, 15.07.2020.

Rangfolge der Handelspartner im Außenhandel der Bundesrepublik Deutschland (2020), Statistisches Bundesamt, 2020, https://www.destatis.de/DE/Themen/Wirtschaft/Aussenhandel/Tabellen/rangfolge-handelspartner.pdf?_blob=publicationFile, 15.07.2020.

\section{Streszczenie}

Celem artykułu jest przybliżenie stanowiska niemieckich partii chadeckich (niem. Christlich-Demokratische Union Deutschlands - CDU i Christlich-Soziale Union - CSU) wobec wystąpienia Zjednoczonego Królestwa Wielkiej Brytanii i Irlandii Północnej z Unii Europejskiej. Poddano w nim analizie dokumenty partyjne oraz wypowiedzi czołowych przedstawicieli CDU i CSU. Artykuł podzielony został na trzy części bezpośrednio powiązane z kwestiami, które najczęściej pojawiały się w wypowiedziach chadeków w kontekście Brexitu.

Słowa-kluczowe: CDU, CSU, W. Brytania, Unia Europejska, Brexit

\section{German Christian Democrats towards Brexit}

\section{Summary}

The aim of the article is to present the position of the German Christian Democrats (Ger. Christlich-Demokratische Union Deutschlands - CDU and Christlich-Soziale Union - CSU) towards the withdrawal of the United Kingdom of Great Britain and Northern Ireland from the European Union. It analyzed party documents and statements by leading representatives of the 
CDU and CSU. The article was divided into three parts directly related to issues that most often appeared in Christian Democrats' statements in the context of Brexit.

Key words: CDU, CSU, Great Britain, European Union, Brexit 
